\title{
The Influences of Product Quality, Price, Word of Mouth And Store Atmosphere Toward Purchasing Decision In Michelle Bakery Margonda Depok
}

\author{
Waseso Segoro ${ }^{1}$, Martina Rinawati Mulianto ${ }^{2}$ \\ \{waseso@staff.gunadarma.ac.id ${ }^{1}$, martinarinawati15@gmail.com $\left.{ }^{2}\right\}$
}

Faculty of Economics, Gunadarma University, Jakarta, Indonesia ${ }^{1,2}$

\begin{abstract}
Along with Indonesian alteration needs, recently consumer needs toward food industry is increasing. High demand from consumer induces yearly increasing of food industry selling in the field of bakery business. Due to that reason, citizens compete to open bakery business. One of them is Michelle Bakery. The aim of this research is to examine the effect of product quality, price, word of mouth, and store atmosphere towards purchasing decision in Michelle Bakery Margonda Depok. The method which is used in this research are validity test, reliability test, double linear regression analysis, likert scale analysis, classic assumption test, coefficient determination test, $\mathrm{t}$ test and $\mathrm{f}$ test. The data was collected by spreading the questionnaire to 100 respondens using Rao Purba technique with 96,04 sample hence it was completed into 100 respondens. This research used spss 17 version to analyse the data. The result showed that partialy product quality variable positively affected toward purchasing decision, price positively affected toward purchasing decision, word of mouth positively affected toward purchasing decission, and store atmosphere positively affected toward purchasing decision.
\end{abstract}

Keyword: product quality, price, word of mouth, store atmosphere, and purchasing decision

\section{INTRODUCTION}

Bread consumption in Indonesia continues to increase. Traditional to modern retailers provide bread handling that has a variety of flavors and shapes. The Food and Beverage Entrepreneurs Association (Gapmmi) said that bread was ranked third after rice and noodles as the staple food of the Indonesian people. Entering 2012, the food and beverage industry is predicted to continue to shine to enliven market competition. According to data obtained from GAPMMI (the Indonesian Food and Beverage Association), the sales volume of the domestic food and beverage business continues to experience a sharp increase. Even according to the results of data recording from the Ministry of Industry and Trade, currently the food, beverage and tobacco sectors make the largest contribution of around $34.45 \%$ to national industrial 
growth. The average period (CAGR) growth of 2010-2014, the Indonesian bread and cake business rose by $14 \%$. While the CAGR growth projection for the 2014-2020 period for the bread and cake business is $10 \%$. Until 2020 , the target of the bread and cake business potential is worth Rp. 20.5 trillion.

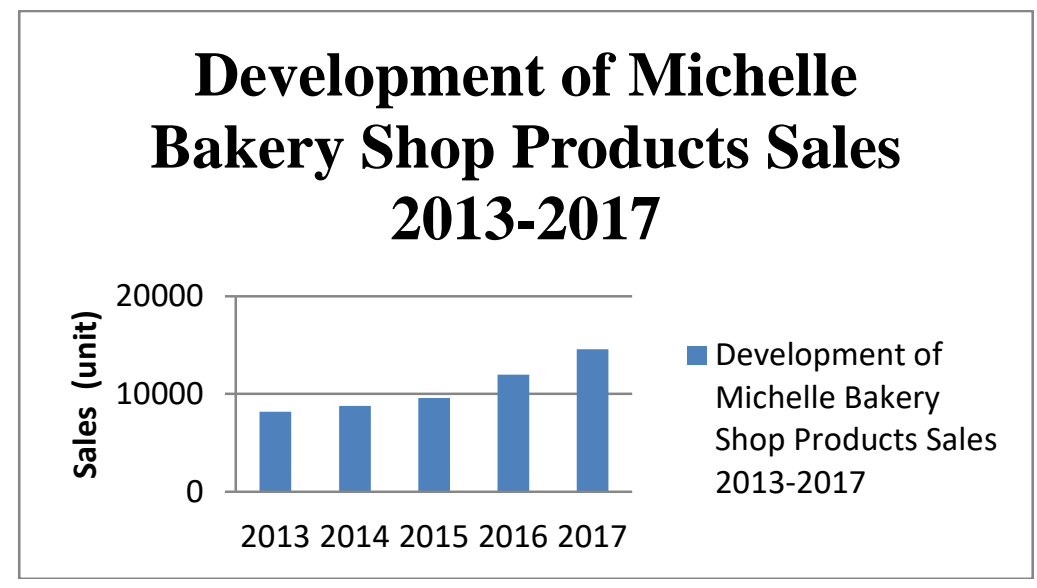

Michelle Bakery is a shop that sells various kinds of bread and cakes. This company sets prices that are relatively cheap and can be reached by all levels of society. This is a very good strategy to survive in competition with similar companie

\section{LITERATURE REVIEW}

\subsection{Product Quality}

Product Quality is is the ability of a product to carry out its functions, including reliability, ease of operation and repair, and other valuable attributes.

\subsection{Price}

Price is the amount of money (plus some products if possible) needed to get a number of combinations of products and services, Dharmmesta dan Irawan (2006 : 349).

\subsection{Word Of Mouth}

Word Of Mouth is s praise, recommendations and customer comments about their experience of services and products that really affect customer decisions or their buying behavior , Hasan (2010)

\subsection{Store Atmosphere}

According to Lamb, Hair, and Mc Daniel in the quotes of Lili Karmela and Jujun Junaedi that, the atmosphere is an overall impression conveyed by the physical layout of the store, decoration, and the surrounding environment 


\subsection{Purchasing Decision}

Purchasing Decision is actions of consumers to want to buy or not to the product. Of the various factors that influence consumers in purchasing a product or service, consumers usually always consider the quality, price and products already known by the public

\subsection{Researh Framework}

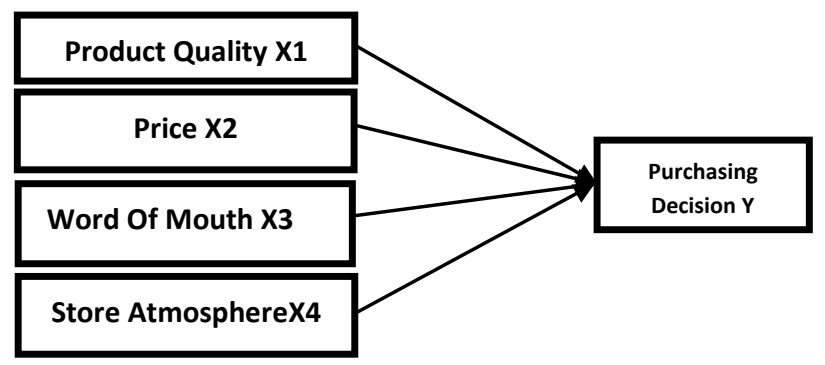

The model explains that the variable Product Quality (X1), Price Variable (X2), Variables of Word Of Mouth (X3) and Store Variable Atmosphere (X4) Influence the Purchasing Decision variable (Y)

\section{RESEARCH METHODS}

\subsection{Population and Samples}

In this study, the population is visitors who come to Margonda Depok Michelle Bakery Shop. The sample research technique used in this study is the Roa Purba formula. Then the sample used in this study using the Roa Purba formula there are 100 respondents

\subsection{Data Collection}

In collecting data the thesis the researcher conducts research by taking the object of research on Michelle Bakery customers. In data collection conducted using primary data. Primary data is by distributing questionnaires to respondents.

\subsection{Data Analysis}

The hypothesis determined in this study will be tested using multiple regression analysis. The analysis was carried out using the help of a computer program namely SPSS (Statistical Package For Social Science) version 17.0 there were several data analysis techniques used in this study namely Instrument Feasibility Test and Classical Assumption Test. 


\section{RESULT AND DISCUSSION}

\begin{tabular}{|c|c|c|c|}
\hline Hypothesis & Statistic Test & Result & Mean \\
\hline $\begin{array}{l}\mathrm{H}_{1} \text { : Product Quality } \\
\text { variable }(\mathrm{X} 1) \\
\text { positively affected } \\
\text { toward Purchasing } \\
\text { Decision }\end{array}$ & $\begin{array}{c}\text { Significant level: } \\
0,000<0,05 \\
\mathrm{~T}_{\text {count }}>\mathrm{t}_{\text {table }} \\
(3,636>0,198)\end{array}$ & $\begin{array}{l}\text { Product Quality } \\
\text { variable } \\
\text { positively } \\
\text { affected toward } \\
\text { Purchasing } \\
\text { Decision (Y). }\end{array}$ & $\begin{array}{l}\text { Products are of good } \\
\text { quality, variant, taste in } \\
\text { accordance with } \\
\text { consumer expectations } \\
\text { and hygienic so that it can } \\
\text { influence the purchase } \\
\text { decision at the Michelle } \\
\text { Bakery Shop }\end{array}$ \\
\hline $\begin{array}{l}\text { H2: Price Variable } \\
\text { (X2) positively } \\
\text { affected toward } \\
\text { Purchasing Decision }\end{array}$ & $\begin{array}{l}\text { Significant Level: } \\
0,033<0,05 \\
\mathrm{~T}_{\text {count }}>\mathrm{t}_{\text {table }} \\
(2,164>0,198)\end{array}$ & $\begin{array}{l}\text { Price Variable } \\
\text { positively } \\
\text { affected toward } \\
\text { Purchasing } \\
\text { Decision (Y) }\end{array}$ & $\begin{array}{l}\text { Michelle Bakery shop } \\
\text { provides affordable prices } \\
\text { for consumers, prices are } \\
\text { in accordance with } \\
\text { product quality, } \\
\text { competitiveness is good } \\
\text { and prices are in line with } \\
\text { taste, so that it can } \\
\text { influence purchasing } \\
\text { decisions at Michelle } \\
\text { Bakery Stores }\end{array}$ \\
\hline $\begin{array}{l}\mathrm{H}_{3}: \text { Word Of Mouth } \\
\text { Variable (X3) } \\
\text { positively affected } \\
\text { toward Purchasing } \\
\text { Decision }\end{array}$ & $\begin{array}{l}\text { Significant Level: } \\
0,004<0,05 \\
\mathrm{~T}_{\text {count }}>\mathrm{t}_{\text {table }} \\
(2,949>0,198)\end{array}$ & $\begin{array}{l}\text { Word Of Mouth } \\
\text { Variable } \\
\text { positively } \\
\text { affected toward } \\
\text { Purchasing } \\
\text { Decision (Y) }\end{array}$ & $\begin{array}{l}\text { Consumers at Michelle } \\
\text { Shop participate in } \\
\text { disseminating information } \\
\text { or promotions, consumers } \\
\text { also often listen to } \\
\text { information from other } \\
\text { people and consumers } \\
\text { recommend to others, so } \\
\text { that there is a positive } \\
\text { influence on purchasing } \\
\text { decisions at Michelle } \\
\text { Bakery Stores }\end{array}$ \\
\hline $\begin{array}{l}\mathrm{H}_{4}: \text { Store Atmosphere } \\
\text { Variable (X4) } \\
\text { positively affected } \\
\text { toward Purchasing } \\
\text { Decision }\end{array}$ & $\begin{array}{c}\text { Significant Level: } \\
0,026<0,05 \\
\mathrm{t}_{\text {hitung }}>\mathrm{t}_{\text {tabel }} \\
(2,265>0,198)\end{array}$ & $\begin{array}{l}\text { Store } \\
\text { Atmosphere } \\
\text { Variable } \\
\text { positively } \\
\text { affected toward } \\
\text { Purchasing } \\
\text { Decision (Y) }\end{array}$ & $\begin{array}{l}\text { Store atmosphere in } \\
\text { Michelle Bakery shop is } \\
\text { comfortable, the } \\
\text { decoration inside is } \\
\text { beautiful, the lighting is } \\
\text { pretty, clean and the } \\
\text { design is good, so there is } \\
\text { a positive influence on } \\
\text { purchasing decisions at } \\
\text { the Michelle Bakery Shop }\end{array}$ \\
\hline
\end{tabular}




\section{CONCLUSION}

From the result and analysis and testing that has been done, the following conclusions are obtaibed:

1. Product Quality Variable positively affected toward Purchasing Decision that means the quality of the products at the Michelle Bakery Shop has been considered good for its consumers

2. Price Variable positively effected toward Purchasing Decision. This proves that the price set by the Michelle Bakery Shop is relatively cheap. The price offered is in accordance with the quality obtained and the price is considered cheaper at the price of similar products.

3. Word Of Mouth Variable positively effected toward Puchasing Decision. This proves that word of mouth at the Michelle Bakery shop is recognized by consumers

4. Store Atmosphere Variable positively effected toward Purchasing Decision. This proves that the situation / atmosphere of the shop at Michelle Bakery Shop is considered good and comfortable for consumers

\subsection{IMPLICATIONS}

The implications of some suggestions from the author include the following:

1. From the results of the study showed that the quality of the product has a positive influence on purchasing decisions, Michelle Bakery Shop must further improve or at least maintain product quality so that purchasing decisions increase. One of the things that can be done is to add a variety of products, one example is to sell various kinds of traditional wet cakes so that the Michelle Bakery Shop can be better known by the outside community and can be more competitive with similar cakes / bread products.

2. From the results of the study shows the price has a positive influence on the purchase decision, Michelle Bakery Shop must continue to maintain a reasonable price for consumers so that consumers will increase, and always be accepted in the community

3. From the results of the study shows that word of mouth has a positive influence on purchasing decisions, Michelle Bakery Shop must keep products and prices so that promotions in the form of word of mouth will still be considered good and give Michelle Bakery Stores good recommendations for the community

4. From the results of the study shows store atmosphere has a positive influence on purchasing decisions, Michelle Bakery Shop must maintain the beauty, decoration, and cleanliness in the shop so that visiting consumers feel comfortable when inside

\subsection{SUGGESTION}

1. For the next researcher who is interested in researching about product quality and price to customer satisfaction, it is better to add other variables such as service quality or brand image and look for wider research objects so that research is more perfect.

2. Researchers can then do research not only in the food industry but can be done in other industries such as the electronics industry, cosmetics, automotive and others. So that research is more varied. 


\section{REFERENCES}

Algifari. Analisa Regresi Teori, Kasus dan Solusi, Edisi 2. Yogyakarta: BPFE, (2002).

Danang Sunyoto.2013.Metodologi Penelitian Akuntansi. Bandung: PT Refika Aditama Anggota Ikapi

Hadi, Sutrisno. Prof., Drs., MA. Ed. 2000. Metodologi Research, Jilid III Yogyakarta

Sugiyono. 2012. Metode Penelitian Kuantitatif Kualitatif dan R\&D. Bandung: Alfabeta.

Sugiyono. 2012. Metode Penelitian Bisnis. Bandung : Alfabeta.

Sugiyono. 2010. Statistika Untuk Penelitian. Bandung: Alfabeta..

Basu Swastha dan Irawan. (2006). Manajemen Pemasaran Modern. Edisi Kedua: Liberty Yogyakarta.

Hasan, Ali. (2010). Marketing dari Mulut ke Mulut. Yogyakarta: Media Pressindo.

Kotler, Philiph. 2002. Manajemen Pemasaran. Edisi Millenium. Jilid 2. PT Prenhallindo. Jakarta 